\title{
Research on Rural Financial Reform Innovation and Sustainable Development Countermeasures in Hebei Province of China
}

\author{
Huang Ying \\ Baoding University, Baoding, China \\ Email: hyingmm@126.com
}

How to cite this paper: Ying, H. (2018) Research on Rural Financial Reform Innovation and Sustainable Development Countermeasures in Hebei Province of China. Journal of Human Resource and Sustainability Studies, 6, 53-60.

https://doi.org/10.4236/jhrss.2018.61026

Received: January 26, 2018

Accepted: March 19, 2018

Published: March 22, 2018

Copyright $\odot 2018$ by author and Scientific Research Publishing Inc. This work is licensed under the Creative Commons Attribution International License (CC BY 4.0). http://creativecommons.org/licenses/by/4.0/

\begin{abstract}
In the process of the reform of the rural financial reform innovation in Hebei Province of China, the government should play a positive leading role. This article argues that the government should accelerate the completion of land ownership work, set the "two rights" value guiding price and perfect the value evaluation system, promote the compulsory "agricultural loan insurance", and gradually built a sustainable and modern rural financial ecology.
\end{abstract}

\section{Keywords}

Hebei Province Rural Finance, Confirmation of Land Right, Modernization Rural Finance Ecology

\section{The Present Situation of Rural Financial Development in the Hebei Province}

China has entered the decisive stage of building a well-off society in an all-round way, and the development of agriculture has entered a crucial period of transformation and upgrading. In 2016, the Hebei Province issued "The 13th Five-Year Plan of the Development of Modern Agriculture in the Hebei Province". The Plan proposed that by 2020 , the province will have made substantial progress in modern agricultural construction, realizing the overall goal of "three breakthroughs, two preconditions and one basic formation". Rural financial service is still a "weak point" to realizing the development of modern agriculture in the Hebei Province, loaning is difficult and expensive [1]. "Speeding up rural financial innovation" is a new requirement for rural financial work in the Hebei Province.

In recent years, the development of rural finance in Hebei is reflected in many 
aspects. The strength and scale of financial support for agriculture, the breadth and depth of service have reached a new level, and the ability of sustainable development of rural financial institutions has achieved a new breakthrough [2]. A variety of bold innovations and practices of new rural financial service model have provided strong support for the development of agricultural modernization. Take the Hebei Rural Credit Cooperative (Commercial Bank) as example, the data show that as of the end of 2016, the province's rural credit system deposits were about 1,100,000,000,000 yuan, 698 billion 600 million yuan of loans, a net increase of 90 billion 227 million yuan than the beginning of the year, an increase of $14.83 \%$, the increased amount of loans has completed $100.25 \%$ of the target at the beginning of the year, the total assets reached about 1,323,500,000,000 yuan, a net increase of 177 billion 509 million yuan compared to the beginning of the year. The balance of agricultural credit cooperatives in the province's agricultural loan is 398 billion 651 million yuan, a net increase of 39 billion 668 million yuan compared with that at the beginning of the year, the growth rate is $11.05 \%[3]$.

The pilot project of mortgage loan of land contract management right has been carry out actively, and the risk compensation fund for rural property right mortgage loan is set up in the Department of Finance in the Hebei Province. Taking Hebei Qiu County as an example, as of the end of 2016, this business started in the two financial institutions of Handan Bank Qiu County Branch and Qiu County Rural Credit Union in Qiu County. The total amount of loans granted was 21.5 million yuan, including 4.5 million yuan for agricultural companies, 16 million yuan for farmers' specialized cooperatives and 1 million yuan for farmers [4].

The Finance Department of the Hebei Province has set up the risk compensation fund for the rural property right mortgage loan, taking the reward form of "post-subsidy", rewarding the financial institution organization, the rural property right transaction center, the issuance of rural property rights of mortgage loans and municipal- and county-level financial sector risk compensation according to certain conditions [5].

\section{Theoretical Research Background}

\subsection{Research on Rural Economic and Financial Support Abroad}

Hellmann and Murdockie Stiglitz (1997) [6] and others put forward the "financial restraint theory", which holds that for developing countries with lower financial development level, financial deepening has great social welfare effect. Therefore, banks should be encouraged to actively open up new markets, especially the vast rural market. But because competitive habits and high transaction costs create inherent instability in the banking system, and the public nature of the information banks have about opening up new markets, not only the banks themselves have no incentive, And free competition doesn't achieve the best results in society. They argue that the government should play an active role in 
creating conditions for Banks by using their own strengths to promote financial deepening and economic growth.

\subsection{Research on Rural Economic and Financial Support in China}

The research on the current situation and problems of rural economic and financial support: Fangyan (2010) [7] analyzes the existing problems of rural finance, and concludes that the rural financial system in our country has insufficient supply of rural financial main body, and the supply of rural financial instruments is single. Sun Yanying (2007) [8] found that the problems of financial support in the development of rural economy in China are insufficient financial resources and and increasing deviation of financial support.

A study on the reasons for the insufficiency of rural economic and financial support: Lu Xueshan (2007) [9] thinks that there are four system defects in the financial supporting agriculture: the difficulty of the policy finance, the failure of the commercial financial market, and the slow development of cooperative finance. Pan Jiang (2003) [10] thinks that the main reasons for the lack of rural financial support are: the credit services of state-owned commercial banks basically withdraw from the rural market: the rapid development of postal savings from rural areas to withdraw a large number of funds; The role of policy finance in supporting agriculture is basically lost, and the reform and management of rural credit cooperatives are divorced from reality.

Their papers are very helpful to today's research, but they do not mention the question of how to deal with the collateral. I will be further studied in this article.

\section{The Restricting Factors of Rural Financial Development in the Hebei Province at Present}

\subsection{Lack of Effective Credit Collateral Is a Key Issue}

After "Guidance on Carrying out Pilot Operation Rights of Rural Contracted Land and Pilot Mortgage Loans for Farmers' Housing Property Rights" was issued by the State Council in 2015, on March 24th, 2016, the Central Bank and various ministries and commissions jointly issued Interim Measures for Pilot Mortgage Loans for Contracted Land in Rural Areas in 2003, with the authorization of the standing committee of the National People's Congress, the People's Bank, together with the relevant ministries and commissions, confirmed 232 pilot counties (cities, districts) for agricultural land mortgage loans and 59 rural housing mortgage pilot counties (cities, districts) [11]. The Hebei Province also actively launched the pilot work of the "two-right mortgage loan "model".

"Two-right mortgage loan" refers to the management right mortgage loan of rural contracted land and the mortgage loan of farmer's housing property right [12]. At present, the largest assets owned by farmers are the contractual land management right and homestead [13]. However, due to the particularity of the "land ownership of farmers" in China, the current laws have very strict restrictions on the circulation of collective land use rights. Financial institutions are 
more likely to require borrowers to provide effective mortgages, but if borrowers breach the contract, how should they dispose of the collateral, and can they lose their homestead and contractual land management rights? This contradiction is the key problem that makes it difficult for farmers to obtain loans with "two rights" as effective collaterals.

\subsection{Inadequate Endogenous and Innovative Capacity of Rural Financial Institutions}

Compared with urban finance, rural finance is more complex with higher risks and lower returns, which is not in line with the nature of the financial industry to avoid risk and make profit, which is the main reason for the lack of endogenous power of the financial industry. As a result of the systematic restriction, the rural financial market lacks the effective market-oriented competition mechanism, and the innovation will of financial institutions at "monopoly" position is not strong.

Although the new Internet financial institutions have more innovative abilities and "de-mortgage" characteristics than traditional financial institutions, at present, they mainly rely on the credit information system. At this stage, the imperfect credit information system in rural areas has become an obstacle for Internet finance to further serve rural areas [14]. At the same time, the influx of financial talents into diversified urban financial institutions results in a shortage of talents in the rural financial sector. For a long time, the lack of professional financial talents who not only master professional financial knowledge but also have a deep understanding of rural financial market has become another reason for the lack of innovative ability of rural financial institutions.

\subsection{The Weak Economic Basis of Rural Areas Seriously Restricts the Development of Rural Financial Industry}

In recent years, the Hebei Province has promulgated a series of important policies on supporting agriculture and benefiting agriculture, but the rural economic base is still relatively weak. Rural economy is the cornerstone of rural financial ecosystem and the survival of the economic conditions, the total amount of rural economy directly affects the scale of rural financial development. Only with the development of rural economy can rural funds increase in supply and demand, so as to improve the financial ecological environment [15]. The Hebei Province has entered the "new normal state" of economic development, the industry pressure continues to increase under the economic development, "de-productivity" and "deleveraging" and other policies have a relatively great negative impact on the overall economy in the short term. The lack of implementation of the preferential agricultural policies and the lagging behind of the trend of the construction of the service system make it more difficult for the rural economy to grow.

\subsection{Lack of Social Services at the Grass-Roots Level}

Reviewing the reform process and achievements of rural finance in the Hebei 
Province, whether it is the establishment of non-commercial agriculture-supporting banks, or the strategic transfer of state-owned commercial banks to rural areas, as well as the reform of rural credit cooperatives system [16], all are mainly implemented under the leadership of the government.

Grass-roots government is the first line of rural work. The working attitude and efficiency of grass-roots government directly affect the progress of projects in rural financial system. In some underdeveloped rural areas, the service concept of grass-roots government is still relatively old, the government staffs attach too much importance to the political tasks and preferential policies issued by the higher authorities, but ignore specific financial problems. The consciousness of "ecological construction" of financial industry is weak, and it is impossible to organize and promote the construction of financial ecological work in local countryside. There is even the phenomenon of excessive intervention of grass-roots government in rural financial behavior [17].

In the early stage of rural financial reform, the leading role of the government is very beneficial to the innovation of system, saving the cost of organization and the cost of implementing the system, and the effective allocation of social resources, but if the government cannot complete the role transfer and promote the formation of sustainable rural financial ecosystem, it will not be conducive to the healthy development of rural finance.

\section{Concrete Suggestions for Speeding up the Reform and Innovation of Rural Finance at Present}

\subsection{Expediting the Promotion of Land Approval Registration}

According to the query platform of national administrative divisions, there were 197 villages and towns and 50,201 villagers' committees in Hebei Province as of September 2017 [18]. The task of land approval registration is huge and complex, but the land right is the premise to solve the problem of the lack of rural credit collateral.

Land approval is to determine the ownership of land, the right to contract, and the right to operate. Prior to that, it was extremely inconvenient for farmers to apply for loans because there was no identifiable collateral, only joint guarantees can be used, and the amount of the loans was relatively small. After confirming the right of land, Land Use Certificates can become a kind of assets to mortgage, thus fundamentally solve the problem of farmers' lack of collateral.

The Hebei province should increase investment, and accelerate the completion of land ownership work. It should establish an authoritative and unified registration system of rural land rights, and public finance should give strong support; It is necessary to establish an effective coordination mechanism and a unified guiding principle for the whole country, so as to avoid multi-pronged policies; the data of cadastral management and registration departments should be integrated to ensure the sharing and consistency of the data. 


\subsection{Set the "Two Rights" Value Guiding Price and Perfect the Value Evaluation System}

Fair, impartial and objective evaluation of the value of rural land management rights and farmers' housing property rights is the basis for rural financial institutions to decide whether or not to lend. At this stage, our province mainly evaluates the value of rural land circulation through third-party evaluation institutions, that is, after the loan farmers put forward the evaluation application, the third party evaluation center evaluates the value of the land according to the present situation of the farmers' land, and the financial institutions use it as a reference for the feasibility of the loan. Alternatively, financial institutions assess themselves and examine the feasibility of lending. The growth of crops is strongly seasonal, so the effectiveness of agricultural loans is very prominent, but in the past, these evaluation methods greatly affected the improving of the lending rate of rural finance.

The author believes that the land value assessment can be completed with the guidance of the local government. On the basis of completing the work of approving of the right to land, the government can further organize research and set the guiding price of "two rights" in each township of the Hebei Province according to the regional economic situation. This price is the benchmark price used by borrowers and credit institutions to assess the value of the "two rights". Put land valuation ahead, in this way, farmers can understand their potential loan amount, and can also refer to their own loan amount to organize agricultural production in a planned way. Farmers know whether they can borrow and how much they can borrow.

This government-led land value evaluation system can effectively solve the problem of value evaluation, and thus greatly improve the speed of lending, and accelerate the activation of rural assets.

\subsection{To Implement Compulsory "Agricultural Loan Insurance" to Solve the Breaching Problem of "Two-Right Mortgage"}

The lack of collateral disposal system of "two rights" is a prominent problem of rural financial loan violation, and also a restrictive factor that hinders the development of rural financial credit. To solve this problem, the government may establish a compulsory "agricultural loan insurance" system in conjunction with insurance companies. The compulsory "agricultural loan insurance" is a kind of compulsory liability insurance purchased by the borrowers in the process of "two rights" mortgage loan. The purpose is that if the borrower fails to repay the loan, the insurance company will be liable for the breach within the limit of liability. The implementation of this policy can effectively protect the legitimate rights and interests of borrowers based on the principle of not changing the nature of the public ownership of land and not breaking the red line of cultivated land, and at the same time relieving the worries of rural credit institutions [19]. To guarantee the rapid return of rural credit funds is a dual benefit guarantee for 
rural borrowers and rural credit institutions, which can effectively solve the problem of the lack of collateral disposal system in the "two-right mortgage loan".

\subsection{The Government Has Gradually Completed the Role Transition from a Strongly Interventionist to a Weak-Intervention Service-Oriented Government}

The government should play an active leading role at present, dispose of the relationship with the market well, understand the natural attributes of the participants in rural finance, and guide and stimulate the main bodies in rural finance to actively help with the development of rural finance. It should give full play to the role of government policy support and supervision, actively build a diversified rural financial system, set up cross-department work coordination mechanism, and improve the rural financial supporting system. It should establish a policy support system to promote rural economic development and encourage rural financial innovation, gradually stimulate the endogenous mechanism of rural financial system, and complete the role transition from strong intervention-oriented to weak-intervention service-oriented government. Finally, construct a sustainable modern rural financial ecology.

\section{Conclusion}

Rural finance in Hebei Province of China is still at the stage of forcible reform dominated by government policy, which has been achieved remarkable achievements. But the evolution of this non-commercial and non-demand oriented mechanism inhibits the further development of rural finance to some extent in the later stage. Focusing on the rural financial development in the $\mathrm{He}$ bei Province, the government should play the positive leading role to accelerate the completion of land ownership work, set the "two rights" value guiding price and perfect the value evaluation system, promote the compulsory "agricultural loan insurance", and provide a good financial environment. Then the transition of role from strong pre-oriented to weak pre-oriented will be completed gradually. Finally a sustainable and modern rural financial ecology can be built.

\section{Funding}

Project: 2017 Social science development research project of the Hebei Province. Project Name: Rural financial innovation research under the new normal of the Hebei Province. Project No. 201703020213.

\section{References}

[1] Han, C.B. (2017) Promoting the Innovation of Rural Financial Services to Achieve the Win-Win Development of Agricultural Modernization and Rural Finance. Ministry of Agriculture.

http://www.chama.org.cn/zxt/hydt/201709/t20170926_5828177.htm 
[2] Dang, W. (2011) Research on the Sustainable Development of Rural Financial Institutions in China. Academic Forum, 11, 142-146.

[3] Hebei Province Rural Credit Cooperative Official Website Data. http://www.hebnx.com/

[4] Gao, Y.J. (2017) Land Mortgage Practice in Qiu County, Financial Times Survey of Rural Land Contracting Right Mortgage in Qiu County, Hebei. Chinese Financial News Network, 2017-03-09. http://www.financialnews.com.cn/ncjr/focus/201703/t20170309_113986.html

[5] Local Scanning, Management of Rural Management, September 2016.

[6] Hellmann, T., Murdock, K. and Stiglitz, J. (1997) Financial Restraint: Towards a New Paradigm, Role of Government in East Asian Economic Development, 163-208.

[7] Fang, Y. (2010) On Financial Support in the Construction of New Socialist Countryside. Rural Economy and Science-Technology, 21, 38-39.

[8] Sun, Y.Y. (2007) Research on Financial Support for Rural Economic Development in China. Ph.D. Thesis, Harbin Engineering University, Harbin.

[9] Lu, X.S. (2007) Financial Support: Institutional Defects and Path Innovation in the Solution of the Three Rural Problems. Dongyue Tribune, 28, 170-172.

[10] Pan, J. (2003) The Countermeasures to Solve the Problem of "Three Farmers" from the Financial Aspect. Southern Finance, 10, 47-49.

[11] Zhang, X.F. (2016) Study on Legal Problems of Mortgage of Farmland Management Rights. Master Thesis, Tianjin University of Commerce, Tianjin.

[12] Guangxi Financing Guarantee Association. http://www.gxrzdb.org/newsshow.aspx?articleid=632\&typeid=3

[13] Cheng, A.A. (2010) Research on the Circulation of the Right to Use the Rural Homestead in China. Journal of Chengdu Institute of Public Administration, 4, 80-82.

[14] Wu, C.Y. (2010) Discussion on the Development and Improvement of the Rural Credit System in the Henan Province. Credit Reference, 4, 24-26.

[15] Yang, K.Y. (2010) The Construction of Rural Financial Ecological Environment. China Market, 10, 80-81.

[16] Shi, Y.R. (2010) Research on the Long-Term Mechanism of Financial Support for Rural Economy in Hebei Province. Hebei Academic Journal, 5, 209-212.

[17] Zhang, X.J. (2013) Reconstruction of New Rural Construction and Rural Financial Ecosystem, Modern Business.

[18] https://baike.baidu.com/item/\%E6\%B2\%B3\%E5\%8C\%97/65777?fr=aladdin

[19] Tang, Y.J. (2016) Research on the Land System Reform of the Communist Party of China Since the 18th National Congress of the Communist Party of China. Master thesis, University of Science and Technology of Hunan, Xiang Tan. 